\title{
FATTY ACID COMPOSITION OF VEGETABLE OILS AND FATS
}

\author{
RUI CARLOS ZAMBIAZI* \\ ROMAN PRZYBYLSKI** \\ MOEMA WEBER ZAMBIAZI*** \\ CARLA BARBOSA MENDONÇA ****
}

\begin{abstract}
The main objective of this work was to identify the fatty acid composition of several vegetable oils and fats. Twenty vegetable oils and fats were analyzed for its fatty acid composition by gas chromatography (GC-FID). Among the evaluated oils the higher contents of saturated fatty acids were found in the coconut and palm fats, that showed above $80 \%$ of saturated fatty acids. Except palm fat, that presented about $50 \%$ in saturated fatty acids, all other oils showed saturated fatty acids below $25 \%$, being the canola oil that presented the highest unsaturated fatty acid content. Furthermore, canola oil, in the same way soybean oil, showed between 8 and $10 \%$ of omega-3 fatty acids. The borage and evening primrose oils differed from the others by presenting appreciable amount of $\gamma$-linolenic acid, and the linseed oil for presenting more than $50 \%$ in linolenic acid. The rice, peanut, cotton and corn oils showed higher content of oleic and linoleic acids.
\end{abstract}

KEY-WORDS: SATURATED FATTY ACIDS; MONOUNSATURATED FATTY ACIDS; POLYUNSATURATED FATTY ACIDS; OMEGA FATTY ACIDS.

* PhD. Food and Nutritional Science, professor titular, Departamento de Ciência dos Alimentos (DCA), Universidade Federal de Pelotas (UFPEL), Pelotas/RS (e-mail: zambiazi@ufpel.tche.br).

** Professor, Doctor, Department of Food and Nutritional Science, University of Manitoba, Winnipeg, Canadá.

*** Nutricionista, UFPEL, Pelotas/RS.

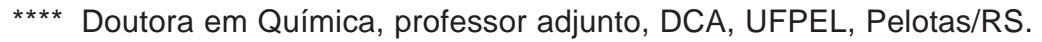




\section{INTRODUCTION}

On vegetable oils, each position on the glycerol molecule may be esterified by a different fatty acid following plant patterns. The most common forms are the triacylglycerols (TAG), in which two or three kind of fatty acid moieties are present in the molecule (CHRISTIE, 1992). Both the physical and chemical characteristics of oils and fats are greatly influenced by the kind and proportion of the fatty acids on the triacylglicerol (SENANAYAKE \& SHAHIDI, 2002; St.ANGELO, 1996).

Fatty acids can be classified in classes as saturated, mono-unsaturated (MUFA) and polyunsaturated (PUFA) fatty acids. On the other hand, the unsaturated ones are classified into series known as omega, being $\omega-9$ considered nonessential to human, and the $\omega-3$ and $\omega-6$ as essential fatty acids, because the latter ones cannot be synthesized by mammals; therefore, it have to be obtained from the diet (ASSIESA et al, 2004; RISTIC \& RISTIC, 2003).

The Greek letter $\omega$ (omega) is used to designate the last carbon of the chain, opposite to the functional carboxylic group. Based on this nomenclature, the polyunsaturated fatty acids are denominated as $\omega-3$ when the first double bond is placed between $\mathrm{C} 3$ and $\mathrm{C} 4$, in relation to the carbon omega ( $C-\omega) ; \omega-6$ when the first double bond is placed between $C 6$ and $C 7$, in relation to C - $\omega$ and $\omega-9$ when the first double bond is placed between C9 and C10, in relation to C- $\omega$. (SOLOMONS \& FRYHLE, 2003).

The predominant fatty acids present in vegetable oils and fats are saturated and unsaturated compounds with straight aliphatic chains. An even number of carbon atoms, from 16 to 18, with a single carboxyl group, is the most common. A number of other minor fatty acids may be present in same vegetable sources, including a small amount of branched chain, cyclic, and odd number straight chain acids (CHRISTIE, 1992; DANIEWSKI et al., 2003; ZAMBIAZI \& ZAMBIAZI, 2000).

An important feature common to most plant origin oils and fats is the high percentage of unsaturated fatty acids in the triacylglycerols. In general, higher degree of unsaturation of a vegetable oils fatty acids, the more susceptible they are to oxidative deterioration (BRADLEY \& MIN, 1992; St.ANGELO, 1996; ZAMBIAZI \& ZAMBIAZI, 2000). Therefore, it is essential to know the composition of fatty acids of an oil or fat, to identify their characteristics and determining more precisely the possible adulterations, as well as to know the stability of these products (St.ANGELO, 1996; ZAMBIAZI, 1999).

Vegetable oils are one of the major components of human diets, comprising as much as $25 \%$ of average caloric intake. The rate of saturated to unsaturated fatty acids is very important for human nutrition. While high levels of saturated fatty acids is desirable to increase oil stability, on the other hand, nutritionally they became undesirable, because high levels of saturated fatty acids are frequently considered do have influence by increasing the concentration of low density lipoproteins (LDL), affecting the ratio of LDL to HDL (high density lipoproteins), promoting clotting and vascular smooth muscle proliferation (EUNJOO, 1994; DZISIAK, 2004; PRZYBYLSKI \& MCDONALD, 1995).

Diet with increasing intake of linoleic and linolenic acids increases HDL-cholesterol and decreases LDH-cholesterol, while higher intake of oleic acid decreases LDL-cholesterol but does not affect HDL-cholesterol levels (LAWTON et al., 2000; PRZYBYLSKI \& MCDONALD, 1995 ).

However, while high levels of polyunsaturated fatty acids are important to the adequate ratio of LDL to HDL-cholesterol, these fatty acid becomes more susceptible to oxidation, even by in vivo peroxidation, resulting in several oxidation products, and many of them results in quality reduction, improving undesirable flavour compounds, generating many toxic effects such as cell injuries, plaque formation, cell membrane cytotoxity and coronary heart disease (BRADLEY \& MIN, 1992; CLARK \& SERBIA, 1991; EUNJOO, 1994; ZAMBIAZI, 1999).

The main objective of this work was to identify the fatty acid composition of twenty vegetable oils and fats, to improve understanding of the oil quality, stability and applicability. 


\section{MATERIAL AND METHODS}

\subsection{MATERIALS}

\subsubsection{Oils}

Twenty vegetable oils and fats with different origin and degree of processing were selected for the study (Table 1). These oils represented a wide variability in chemical composition related to fatty acid composition.

Fresh oils were obtained directly from processors, and stored at $-40^{\circ} \mathrm{C}$ in the absence of light until analysed. All oils were packed in opaque plastic containers with capacity of one or four litters.

TABLE 1 - TYPE AND ORIGIN COUNTRY OF THE VEGETABLE OILS USED IN THE STUDY

\begin{tabular}{lll}
\hline Code & Oils & Country of origin \\
\hline BOR & Borage & Canada \\
CAN & Canola & Canada \\
COR & Corn & Brazil \\
CRN & Corn & USA \\
COC & Coconut & USA \\
COT & Cottonseed & USA \\
EPR & Evening Primrose & Canada \\
FCO & Linseed & Canada \\
OEV & ExtraVirgin Olive & Spain \\
POR & Olive Pomace & Spain \\
ORF & Olive & Spain \\
PAL & Palm & Malaysia \\
PLK & Palm Kernel & Malaysia \\
PEA & Peanut & USA \\
RBO & Rice Bran & Brazil \\
RIO & Rice Bran & USA \\
SUR & Sunflower & Canada \\
SUN & Sunflower & Brazil \\
SOY & Soybean & Brazil \\
SYB & Soybean & USA \\
\hline
\end{tabular}

${ }^{1}$ Refined, bleached and deodorized oils; ${ }^{2}$ Cold pressed oil.

\subsection{EVALUATION OF OIL COMPOSITION}

\subsubsection{Fatty acid composition}

Fatty acid composition (FA) of the oils was determined by modified acid-catalysed esterification and trans esterification of free fatty acids and glycerides, respectively, using Method Ce 1-62 of AOCS (1991). Approximately $80 \mathrm{mg}$ of oil was dissolved in $1 \mathrm{~mL}$ of petroleum ether, followed by the addition of $12 \mathrm{~mL}$ of a $0.5 \mathrm{~N}$ methanolic-hydrochloric acid solution. Samples were placed in an oven at $65^{\circ} \mathrm{C}$ for 1 hour, periodically agitated, cooled, and then $6 \mathrm{~mL}$ of water and $5 \mathrm{~mL}$ of isooctane were added to the samples. The samples were shaked, and a part of the organic layer was taken to determine the fatty acid composition by gas chromatography (GC). The methylated samples were 
placed in an autosampler (Hewlett Packard model 7673, Avondale-USA), and 0,5 mL of sample was injected into the gas chromatograph (Hewlett Packard model 5890A, Avondale-USA) equipped with a split injector and a flame ionization detector (FID). A capillary column, $30 \mathrm{~m} \times 0,25 \mathrm{~mm}$ internal diameter, coated with $0,2 \mathrm{~nm}$ of cyanopropylphenyl-bicyanopropyl polysiloxane phase (Restek, Bellefonte, USA) was used. An initial column temperature of $130^{\circ} \mathrm{C}$ was used for one min, then programmed to $145^{\circ} \mathrm{C}$ at the rate of $3^{\circ} \mathrm{C} / \mathrm{min}$, then to $165^{\circ} \mathrm{C}$ at the rate of $1.2^{\circ} \mathrm{C} / \mathrm{min}$, and finally to $220^{\circ} \mathrm{C}$ at the rate of $2.5^{\circ} \mathrm{C} / \mathrm{min}$. At each stage of programming, the temperature was held for $1.0,1.5$, 0.5 and $1.5 \mathrm{~min}$, respectively. The injector and detector were held at $250^{\circ} \mathrm{C}$. The relative percentage (area \%) of the fatty acids was determined using a reference mixture of methyl esters of fatty acids. The analyses were carried out in triplicate.

\section{RESULTS AND DISCUSSION}

The area percent of the saturated fatty acid composition of the vegetable oils is provided in Table 2.

\section{TABLE 2 - SATURATED FATTY ACID COMPOSITION OF VEGETABLE OILS AND FATS (AREA \%)}

\begin{tabular}{clllllllllll}
\hline \multirow{2}{*}{ Oils $^{\star^{1}}$} & \multicolumn{1}{l}{ Saturated fatty } & acids $\star^{{ }^{2}}$ & & & & & & & & \\
\cline { 2 - 12 } & $\mathrm{C}_{8: 0}$ & $\mathrm{C}_{10: 0}$ & $\mathrm{C}_{12: 0}$ & $\mathrm{C}_{14: 0}$ & $\mathrm{C}_{16: 0}$ & $\mathrm{C}_{17: 0}$ & $\mathrm{C}_{18: 0}$ & $\mathrm{C}_{20: 0}$ & $\mathrm{C}_{22: 0}$ & $\mathrm{C}_{24: 0}$ & Total \\
\hline BOR & - & - & - & 0,06 & 8,75 & 0,06 & 3,46 & 0,22 & 0,30 & 0,11 & 12,96 \\
CAN & - & - & - & 0,06 & 3,75 & 0,04 & 1,87 & 0,64 & 0,35 & 0,27 & 6,98 \\
CRN & - & - & - & - & 10,34 & 0,07 & 2,04 & 0,44 & 0,31 & 0,26 & 13,46 \\
COR & - & - & - & & 10,47 & 0,08 & 2,02 & 0,39 & 0,76 & 0,15 & 13,87 \\
SUN & - & - & - & 0,06 & 5,70 & 0,04 & 4,79 & 0,30 & 1,16 & 0,31 & 12,36 \\
SUR & - & - & - & 0,05 & 5,76 & 0,05 & 4,76 & 0,30 & 0,78 & 0,22 & 11,92 \\
COT & - & - & - & 0,77 & 21,87 & 0,08 & 2,27 & 0,26 & 0,36 & 0,12 & 25,73 \\
EPR & - & - & - & 0,04 & 5,47 & 0,07 & 1,83 & 0,30 & 0,31 & 0,09 & 8,11 \\
FCO & - & - & - & 0,05 & 4,81 & 0,05 & 3,03 & 0,20 & - & 0,01 & 8,15 \\
SOY & - & - & - & 0,06 & 9,90 & 0,10 & 3,94 & 0,41 & 0,48 & 0,21 & 15,10 \\
SYB & - & - & - & 0,06 & 9,63 & 0,11 & 4,38 & 0,35 & 0,67 & 0,24 & 15,12 \\
OEV & - & - & - & - & 8,70 & 0,17 & 3,47 & 0,46 & 0,13 & 0,05 & 12,98 \\
OPR & - & - & - & 0,02 & 9,31 & 0,09 & 3,20 & 0,55 & 0,25 & 0,11 & 13,53 \\
ORF & - & - & - & - & 10,84 & 0,14 & 3,59 & 0,50 & 0,15 & 0,06 & 15,28 \\
PEA & - & - & - & 0,03 & 9,40 & 0,12 & 2,65 & 1,38 & 3,14 & 1,66 & 18,38 \\
RBO & - & - & - & 0,21 & 16,90 & - & 1,78 & 0,61 & 0,77 & 0,41 & 20,68 \\
RIO & - & - & - & 0,29 & 14,24 & - & 2,13 & 0,75 & 0,33 & 0,48 & 18,22 \\
PAL & - & - & - & 1,12 & 42,70 & 0,11 & 4,55 & 0,39 & 0,58 & 0,06 & 49,45 \\
PLK & 3,43 & 3,23 & 46,14 & 16,17 & 8,65 & - & 2,27 & 0,15 & - & 0,30 & 80,34 \\
COC & 6,38 & 5,56 & 45,46 & 18,82 & 10,08 & - & 4,31 & 0,08 & - & - & 90,69 \\
\hline
\end{tabular}

${ }^{* 1} \mathrm{BOR}=$ borage$; \mathrm{CAN}=$ canola; $\mathrm{CRN} / \mathrm{COR}=$ corn $;$ SUN/SUR = sunflower; $\mathrm{COT}$ = cottonseed; EPR = evening primrose; $\mathrm{FCO}$ = linseed; SOYISYB = soybean; OEV = extra virgen olive; POR = olive pomace; ORF = olive; PEA = peanut; $\mathrm{RBO} / \mathrm{RIO}=$ rice bran; $\mathrm{PAL}=$ palm; $\mathrm{PLK}=$ palm kernel; $\mathrm{COC}=$ coconut;

${ }^{* 2} \mathrm{C}_{8: 0}=$ caprílic $; \mathrm{C}_{10: 0}=$ capric $; \mathrm{C}_{12: 0}=$ lauric $; \mathrm{C}_{14: 0}=$ miristic $; \mathrm{C}_{16: 0}=$ palmitic; $\mathrm{C}_{17: 0}=$ margaric $; \mathrm{C}_{18: 0}=$ stearic $; \mathrm{C}_{20: 0}=$ arachidic; $\mathrm{C}_{22: 0}=$ behenic; $\mathrm{C}_{24: 0}=$ lignoceric. 
The percentage of the total saturated fatty acid content changed from $6,98 \%$ (canola oil) to $90,71 \%$ (coconut fat). Following the general rule, where the major fatty acid present in the oils showed an even number of carbon atoms (CHRISTIE, 1992).

Except for palm kernel (PLK) and coconut (COC) fats, palmitic acid $\left(\mathrm{C}_{16: 0}\right)$ was the major saturated fatty acid for all oils, followed by stearic acid $\left(C_{18: 0}\right)$. Only trace of myristic $\left(C_{14: 0}\right)$, margaric $\left(C_{17: 0}\right)$, behenic $\left(\mathrm{C}_{22: 0}\right)$ and lignoceric $\left(\mathrm{C}_{24: 0}\right)$ fatty acids were found.

Peanut oil (PEA) showed the highest long chain fatty acid content, comprising $6,18 \%$ of arachidic, behenic and lignoceric fatty acids. However, this oil presented the highest content of saturated fatty acids between sixteen and eighteen carbon atoms.

All samples presented total saturated fatty acid content less than one fourth of the total fatty acid content (saturated and unsaturated fatty acids), except for palm (PAL, PLG, PLK) and coconut (COC) fats.

The relationship between the saturated and polyunsaturated fatty acid content is expressed as $\mathrm{P} / \mathrm{S}$ index. In the diet, it is important the index value be higher than 1 , due to the essential character of the linoleic fatty acid ( $\omega-6)$ (WHO 1982). Several studies indicate that the P/S relation influences in the level of nutrient metabolization in the body, and as the proportion increases a smaller deposition of lipids (LAWTON et al., 2000). The values of the P/S indexes of the oil and fats studied are shown in Table 3.

Canola (CAN), evening primrose (EPR) and linseed (FCO) oils showed a range of saturated fatty acid composition between 7-8\%. Among these oils, only canola oil is normally commercialized; therefore, following nutritional concern, that presumes lower consume of saturated fatty acids in the diets, canola oil was the one that presented the best composition regarding the saturated fatty acid content (PRZYBYLSKI \& MCDONALD, 1995).

Corn (COR, CRN), sunflower (SUN, SUR), soybean (SOY, SYB) and olive (OEV, OPR, ORF) oils showed a total saturated fatty acid ranging from 12 to $15 \%$, being considered useful by consumed as salad oils (McKENZIE \& TAYLOR, 1996; QUINTEIRO \& VIANNI, 1995; RIZZARDI, et al., 1993).

Peanut and rice oils, with saturated fatty acids ranging from 18 to $25 \%$, are considered good sources for cooking and short term frying process, due to their relatively higher saturated fatty acid content, and consequently higher stability (CLARK \& SERBIA, 1991; McKENZIE \& TAYLOR, 1996).

Palm fat (PAL) presented almost $50 \%$ of the total fatty acids as saturated ones, with more than $50 \%$ as palmitic acid. This composition, besides the tendency of $\beta$ polymorphism structure of the palmitic acid, makes palm fat as good oil for deep frying process, and excellent source for blending oils for achieving specific properties for several uses, as source of margarines and bakery products application (FREITAS et al., 1998; McKENZIE \& TAYLOR, 1996; VIEIRA, REGITANO-DÀRCE \& OETTERER, 1997).

Coconut fat (COC) and palm kernel oil (PLK) showed different pattern of saturated fatty acid composition. In both oils, lauric was the major fatty acid present, comprising about $45 \%$ of the total fatty acid content (saturated and unsaturated fatty acids). Caprilic and capric short chain fatty acid also were present in significative amounts, besides myristic, palmitic and stearic fatty acids. In both oils, the highest saturated fatty acid content presented eight to sixteen carbon atoms. Due to a higher content of low chain fatty acids, mainly as lauric acid, these oils are very used for pharmaceutical application, mainly for detergents, soaps and similar products (PENEDO \& COELHO, 1997; VIEIRA, REGITANO-DÀRCE \& OETTERER, 1997).

By comparing the saturated fatty acid composition of oils from different countries (CRN and COR; SUN and SUR; SOY and SYB; RBO and RIO), it was observed that only rice bran oil showed a 2,5\% difference, mainly due to the palmitic acid content; nevertheless, practically no differences were observed in the other oils composition.

Oleic $\left(\mathrm{C}_{18: 1}\right)$ and linoleic $\left(\mathrm{C}_{18: 2}\right)$ acids were the major unsaturated fatty acids present in all oils, being the others present only in trace amounts, except for borage (BOR), evening primrose (EPR) and linseed (FCO) oils. 
The fatty acid composition of borage (BOR) and evening primrose (EPR) oils were very distinct, due to the presence of $\gamma$-linolenic acid (DIRAMAN \& HISIL, 2003; SENANAYAKE, \& SHAHIDI, 2002; TOR \& YI, 2001), with $22,75 \%$ and 9,60\%, respectively. This makes evening primrose oil as the richest source of $\omega-6(74,00 \%)$, and also makes it the richest source of the total polyunsaturated fatty acids (PUFA) with $83,90 \%$.

\section{TABLE 3 - UNSATURATED FATTY ACID COMPOSITION OF VEGETABLE OILS AND FATS (AREA \%)}

\begin{tabular}{|c|c|c|c|c|c|c|c|c|c|c|c|c|c|}
\hline \multirow[b]{2}{*}{ Oils $\star^{x^{1}}$} & \multicolumn{13}{|c|}{ Unsaturated fatty acids ${ }^{\star^{2}}$} \\
\hline & $\mathrm{C}_{16: 1}$ & $\mathrm{C}_{17: 1}$ & $\mathrm{C}_{18: 1}$ & $\mathrm{C}_{18: 2}$ & $\mathrm{C}_{18: 3}$ & $\mathrm{C}_{20: 1}$ & $\mathrm{C}_{20: 2}$ & $\mathrm{C}_{22: 1}$ & $\mathrm{C}_{22: 2}$ & $\mathrm{C}_{24: 1}$ & MUFA & PUFA & $\begin{array}{l}\mathrm{P} / \mathrm{S}^{3} \\
\text { Index }\end{array}$ \\
\hline BOR & 0,29 & 0,07 & 16,52 & 38,47 & $\begin{array}{l}0,22 \\
22,75^{\star}\end{array}$ & 4,05 & 0,35 & 2,23 & - & 2,09 & 25,25 & 61,79 & 4,77 \\
\hline EPR & - & 0,06 & 7,50 & 74,00 & $\begin{array}{l}0,16 \\
9,60^{*}\end{array}$ & 0,24 & 0,14 & - & - & 0,19 & 7,99 & 83,90 & 10,34 \\
\hline CAN & 0,21 & - & 62,41 & 20,12 & 8,37 & 1,54 & 0,11 & - & - & 0,26 & 64,42 & 28,60 & 4,10 \\
\hline CRN & - & - & 25,54 & 59,27 & 1,07 & 0,37 & 0,09 & - & - & 0,20 & 26,11 & 60,43 & 4,49 \\
\hline COR & - & 0,05 & 24,23 & 60,38 & 0,99 & 0,28 & 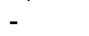 & - & - & 0,20 & 24,76 & 61,37 & 4,42 \\
\hline SUN & - & 0,06 & 15,26 & 71,17 & 0,45 & 0,22 & 0,09 & - & - & 0,39 & 15,93 & 71,71 & 5,80 \\
\hline SUR & 0,06 & 0,03 & 16,86 & 70,69 & 0,28 & 0,16 & 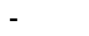 & - & - & - & 17,11 & 70,97 & 5,95 \\
\hline СОT & 0,47 & 0,11 & 16,61 & 56,35 & 0,33 & 0,14 & 0,10 & - & - & 0,16 & 17,49 & 56,78 & 2,20 \\
\hline $\mathrm{FCO}$ & - & 0,12 & 21,42 & 15,18 & 54,24 & 0,40 & 0,39 & - & - & 0,10 & 22,04 & 69,81 & 6,56 \\
\hline SOY & 0,08 & 0,08 & 21,35 & 56,02 & 7,15 & 0,22 & 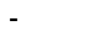 & - & - & - & 21,73 & 63,17 & 4,18 \\
\hline SYB & 0,04 & 0,01 & 23,44 & 52,92 & 7,60 & 0,36 & 0,12 & - & 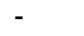 & 0,07 & 23,92 & 60,64 & 4,01 \\
\hline OEV & 0,51 & 0,25 & 76,34 & 8,64 & 0,75 & 0,34 & - & - & 0,19 & 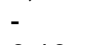 & 77,44 & 9,58 & 0,74 \\
\hline OPR & 0,73 & 0,14 & 74,00 & 10,33 & 0,77 & 0,40 & - & - & - & 0,10 & 75,37 & 11,10 & 0,82 \\
\hline ORF & 0,92 & 0,21 & 75,55 & 7,01 & 0,66 & 0,32 & - & - & 0,05 & - & 77,00 & 7,72 & 0,50 \\
\hline PEA & 0,06 & 0,01 & 48,71 & 31,06 & 0,23 & 1,43 & - & 0,12 & - & - & 50,33 & 31,29 & 1,70 \\
\hline RBO & - & - & 40,50 & 36,20 & 1,60 & 0,53 & 0,11 & - & - & 0,38 & 41,41 & 37,91 & 1,83 \\
\hline RIO & - & - & 43,87 & 36,28 & 0,99 & 0,64 & - & - & - & . & 44,51 & 37,27 & 2,04 \\
\hline PAL & - & 0,06 & 39,37 & 10,62 & 0,21 & 0,17 & - & - & - & 0,06 & 39,66 & 10,83 & 0,22 \\
\hline PLK & - & - & 16,46 & 2,76 & - & 0,17 & - & - & - & 0,27 & 16,90 & 2,76 & 0,03 \\
\hline $\mathrm{COC}$ & - & - & 7,45 & 1,80 & - & 0,06 & - & - & - & 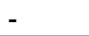 & 7,51 & 1,80 & 0,02 \\
\hline
\end{tabular}

${ }^{*} \mathrm{C}_{\gamma 18: 3}(\gamma$ - linolenic acid $)$.

${ }^{* 1} \mathrm{BOR}=$ borage; CAN = canola; CRN/COR = corn; SUN/SUR = sunflower; COT = cottonseed; EPR = evening primrose; FCO = linseed; SOY/SYB = soybean; OEV = extra olive virgen; OPR = olive pomace; ORF- olive; PEA = peanut; $\mathrm{RBO} / \mathrm{RIO}=$ rice bran; $\mathrm{PAL}=$ palm; $\mathrm{PLK}=$ palm kernel; $\mathrm{COC}=$ coconut

${ }^{* 2} \mathrm{C}_{16: 1}=$ palmitoleic; $\mathrm{C}_{17: 1}=$ miristoleic; $\mathrm{C}_{18: 1}=$ oleic; $\mathrm{C}_{18: 2}=$ linoleic; $\mathrm{C}_{18: 3}=$ linolenic; $\mathrm{C}_{20: 1}=$ gadoleic; $\mathrm{C}_{20: 2}=$ eicosadienoic; $\mathrm{C}_{22: 1}=$ erucic $; \mathrm{C}_{22: 2}=$ docosodienoic; $\mathrm{C}_{24: 1}=$ nervonic.

MUFA $=$ total monounsaturated fatty acids. PUFA = total polyunsaturated fatty acids.

*3 Polyunsaturated/Saturated Index.

Borage oil was the only one that showed significant amounts of long chain unsaturated fatty acids, over 20 carbon atoms, attempting to $8,95 \%$. These oils are essentially used in cosmetics and pharmaceuticals application, such as encapsulates than claim health foods (McKENZIE \& TAYLOR, 1996).

Linseed oil was the richest one in $\omega-3$ fatty acid (TOR \& YI, 2001) with $54,24 \%$ of $\alpha$ - linolenic acid. Linolenic acid is a $\omega-3$ polyunsaturated fatty acid that plays an important role in the regulation of biological functions, prevention and treatment of a great number of human diseases such as heart and inflammatory diseases (SHAPIRO, 2003; VANSCHOONBEEK \& MAAT, 2003; WEN \& CHEN, 2003). Nevertheless, as the amount of polyunsaturated fatty acid content increases, oxidation reactions also are more predictable to occur following an oxidation or in vivo peroxidation process. The higher content of linolenic acid makes linseed oil unprofitable for human consumption, being used in paints and varnishes industry (GUIL-GUERRERO, CAMPRA MADRID \& NAVARRO JUAREZ, 2003; McKENZIE \& TAYLOR, 1996; TOR \& YI, 2001). 
Canola (CAN) and soybean (SOY,SYB) oils also showed linolenic acids, ranging from 7-8\%, what is considered adequate for giving $\omega-3$ source, and allied to the other fatty acid content, relatively good oil stability at room temperature (QUINTEIRO \& VIANNI, 1995). Even with similar linolenic acid content canola (CAN) oil showed different pattern from soybean (SOY,SYB) oil due to higher canola content in MUFA $(64,42 \%)$ against similar amounts of PUFA (61-63\%) in soybean oil. The lower saturated and higher monounsaturated fatty acid content, makes canola oil nutritionally more adequate than soybean oil for salad and cooking purpose (PRZYBYLSKI \& McDONALD, 1995).

It is known that the excessive consumption of saturated fatty acids is related to the increase of the plasmatic cholesterol and the obesity (SALES et al., 2005). On the other hand, the consumption of polyunsaturated (PUFA) and monounsaturated fatty acids (MUFA) it has been recommended to improve the lipidic profile in relation to the saturated fatty acids. However, several studies (ERITSLAND, 2000; YU-POTH, 2000) indicates that rich diets in PUFA are not excepted of negative effects, having been demonstrated that those fatty acids may provoke an increase in the LDLcholesterol oxidation and reduction of the HDL-cholesterol levels. There is a tendency in increasing the recommendations of MUFA consumption, that seems not to affect the HDL levels, and also it may act reducing the LDL and triacylglicerols blood levels, that makes it more effective in the prevention of heart diseases (SALES et al., 2005).

Corn oils (CRN,COR) showed a similar content of PUFA than soybean oils (SOY,SYB) (LAWTON et al., 2000) however, presented lower amount of linolenic fatty acids $\left(C_{18: 3}\right)$ that was compensated by a higher amounts of either oleic $\left(\mathrm{C}_{18: 1}\right)$ and linoleic $\left(\mathrm{C}_{18: 2}\right)$ fatty acids.

Olive oils (OEV,OPR,ORF) are nutritionally considered one of the best salad vegetable oil due to the higher monounsaturated fatty acid content (FREITAS et al., 1998), presented the highest content of MUFA (75-77\%), mainly due to presence of $\omega$-3 oleic acid $\left(C_{18: 1}\right)$, and also for presenting the ration of 10-13:1 of linoleic to linolenic acid (DANIEWSKI et al., 2003).

Sunflower oil (SUN, SUR) also showed high PUFA content (around 71\%), but being the linoleic acid $\left(\mathrm{C}_{18: 2}\right)$ as the major fatty acid, even when comparing with all other oils, also making this oil as good salad oil source (DZISIAK, 2004; McKENZIE \& TAYLOR, 1996; RIZZARDI et al. 1993).

Rice bran oil (RBO, RIO), with about $80-82 \%$ of unsaturated fatty acids, showed a similar distribution between total MUFA e PUFA content, what was not found in the other oils. Such as peanut oil, due to the proportion of saturated and unsaturated fatty acids, rice bran oil is considered good source for cooking and short term frying process (McKENZIE \& TAYLOR, 1996; PRZYBYLSKI \& MCDONALD, 1995).

The highly saturated oils (PAL,PLK,COC) showed oleic acid $\left(\mathrm{C}_{18: 1}\right)$ as the major unsaturated fatty acid (ERITSLAND, 2000; RIZZARDI et al., 1993). However, cottonseed oil (COT), also with high level of saturated fatty acids $(25,73 \%)$ did not show up the same trend by presenting $56,35 \%$ of linoleic acid $\left(\mathrm{C}_{18: 2}\right)$.

The location or variety of the seeds seems not markedly effected on the unsaturated fatty acid composition, which can be seem comparing sunflower (SUN,SUR), corn (CRN,COR) and soybean (SOY,SYS) oils processed in different countries. Only rice bran (RIO,RBO) oils showed a difference of $3 \%$ in MUFA content due to variation on the oleic acid $\left(\mathrm{C}_{18: 1}\right)$ content, but that difference may occur even in oils from same region, due to small differences in climate, soil and seed variety (RIZZARDI et al., 1993).

\section{CONCLUSION}

The borage and evening primrose oils differed from the others by presenting appreciable amount of $\gamma$-linolenic acid (10-20\%), and the linseed oil for presenting more than $50 \%$ in linolenic acid.

Canola and soybean oils showed as rich sources of unsaturated fatty acids, containing 8-10\% of $\omega-3$ fatty acids. 
The rice, peanut, cotton and corn oils, showed higher content of unsaturated fatty acids (more than $75 \%$ ) than saturated ones, mainly due to the distribution between oleic and linoleic acids.

The highest content of the evaluated vegetable oils show less than $40 \%$ of saturated fatty acids in relation to total content of fatty acids, being the P/S index stablished between 1 to 14 of the 20 oils and fats analyzed.

The location or variety of the seeds seems not markedly effected on the fatty acid composition.

The fatty acid composition of an oil or fat is a very important factor in the stability determination and main application definition. This factor is also associated to the harmful impact in the human health.

\section{RESUMO}

\section{COMPOSIÇÃO EM ÁCIDOS GRAXOS DE ÓLEOS E GORDURAS VEGETAIS}

O principal objetivo deste trabalho foi identificar a composição em ácidos graxos de diversos óleos e gorduras vegetais. Vinte óleos e gorduras vegetais foram avaliados quanto a composição em ácidos graxos por cromatografia a gás (GC-FID). Entre os óleos estudados, os maiores teores em ácidos graxos saturados foram encontrados nas gorduras de coco e de semente de palma, que apresentaram mais de $80 \%$ de ácidos graxos saturados. A exceção da gordura de palma, com cerca de $50 \%$ em ácidos graxos saturados, todos os outros óleos revelaram percentuais em ácidos graxos saturados abaixo de $25 \%$, sendo o óleo de canola o que apresentou maior percentual em ácidos graxos insaturados. Além disso, o óleo de canola e de soja apresentaram entre 8 e 10\% de ácido ômega-3. Os óleos de borragem e prímula diferenciaram-se dos demais pelas quantidades apreciáveis de ácido gama-linolênico, e o óleo de linhaça por apresentar mais de $50 \%$ em ácido linolênico. Os óleos de arroz, amendoim, algodão e de milho evidenciaram maiores percentuais dos ácidos graxos oléico e linoléico.

PALVRAS-CHAVE: ÁCIDOS GRAXOS SATURADOS; ÁCIDOS GRAXOS MONOINSATURADOS; ÁCIDOS GRAXOS POLIINSATURADOS; ÁCIDOS GRAXOS ÔMEGA.

\section{REFERENCES}

1 AOCS. Official and tentative methods of the American Oil Chemists' Society. $3^{\text {rd }}$ ed. Champaign, IL, 1991.

2 ASSIESA, J.; LOKA, A.; BOCKTINGA, C.L.; WEVERLINGB, G.J.; LIEVERSEC, R.; VISSERD, I.; ABELINGE, N.G.G.M.; DURANE, M.; SCHENEA, A.H. Fatty acids and homocysteine levels in patients with recurrent depression: an explorative pilot study. Prostaglandins, Leukotrienes and Essential Fatty Acids, v.70, p.349-356, 2004.

3 BRADLEY, D.G.; MIN, D.B. Singlet oxygen oxidation of foods. Critical Review Food Science and Nutrition, v.31, n.3, p.211-236, 1992.

4 CHRISTIE, W.W. Gas chromatography and lipids: a practical guide. Ayr, Scotland: The Oil Press, 1992.

5 CLARK, W.L.; SERBIA, G.W. Safety aspects of frying fats and oils. Food Technology, February, p.84-89, 1991.

6 DANIEWSKI, M.; JACORZYNSKI, B.; FILIPEK, A.; BALAS, J.; PAWLICKA, M.; MIELNICZUK, E. Fatty acids content in selected edible oils. Roczniki-Panstwowego-Zakladu-Higieny, v.54, n.3, p.263-267, 2003.

7 DIRAMAN, H.; HISIL, Y. Analysis of fatty acid cis-trans isomers in different oils and fats by using capillary gas chromatography with different polarity columns. Gida, v.28, n.5, p.513-521, 2003.

8 DZISIAK, D. New oils reduce saturated and trans fats in processed foods. Cereal Foods World, v.49, n.6, p.331-333, 2004.

9 ERITSLAND, J. Safety considerations of polyunsaturated fatty acids. American Journal of Clinical Nutrition, v.71, n.1, p.197-201, 2000. 
10 EUNJOO, H.K. Linoleic acid hydroperoxide induced peroxidation of endothelial cell phospholipids and cytotoxicity. Free Radical Biological Medicine, v.17, n.4, p.285-295, 1994.

11 FREITAS, S.P.; SILVA, F.C.; LAGO, R.C.A. Efeito de enzimas hidrolíticas no comportamento reológico do óleo de palma cru. Ciência e Tecnologia Alimentos, Campinas, v.18, n.1, p.127-130, 1998.

12 GUIL-GUERRERO, J.L.; CAMPRA-MADRID, P.; NAVARRO-JUAREZ, R. Isolation of some PUFA from edible oils by argentated silica gel chromatography. Grasas y Aceites, v.54, n.2, p.116-121, 2003.

13 LAWTON, C.L.; DELARGY, H.J.; BROCKMAN, J.; SIMITH, R.C.; BLUNDELL, J.E. The degree of saturation of fatty acids influences post-ingestive satiety. British Journal of Nutrition, v.83, n.5, p.473-482, 2000.

14 McKENZIE,S.; TAYLOR, D.C. Seed oils: a new age. Plant Biotechnology, v.1,n.1, p.1-4, 1996.

15 PENEDO, P.L.M.; COELHO, G.L.V. Purificação de óleos vegetais por extração com $\mathrm{CO}_{2}$ supercrítico. Ciência e Tecnologia de Alimentos, Campinas, v.17, n.4, p.380-383, 1997.

16 PRZYBYLSKI, R.; MCDONALD, B.E. Development and processing of vegetable oils for human nutrition. Illinois: The Oil Press/ AOCS,1995.

17 QUINTEIRO, L.M.C.; VIANNI, R. Características e estabilidade de óleos de soja. Ciência e Tecnologia de Alimentos, Campinas, v.15, n.1, p.29-36, 1995.

18 RISTIC, V.; RISTIC, G. Role and importance of dietary polyunsaturated fatty acids in the prevention and therapy of atherosclerosis. Med. Pregl. v.56, n.1-2, p.50-53, 2003.

19 RIZZARDI, M.A.; SILVA, P.R.F.; GUTKOSKI, L.C.; ROCHA, A.B. Influência de prática e manejo e cultivares no teor e composição de ácidos graxos do óleo de girassol. Boletim da Sociedade Brasileira de Ciência e Tecnologia de Alimentos, Campinas, v.27, n.1, p.24-31, 1993

20 SAlES, R. L.; COSTA, N. M.B.; MONTEIRO, J. B. R.; PELUZIO, M. G.; COELHO, S. B.; OLIVEIRA, C. G. de; MATTES, R. Efeitos dos óleos de amendoim, açafrão e oliva na composição corporal, metabolismo energético, perfil lipídico e ingestão alimentar de indivíduos eutróficos normolipidêmicos. Revista da Nutrição, Campinas, v.18, n.4, p.499-511, 2005.

21 SHAPIRO, H. Could $\omega-3$ polyunsaturated fatty acids reduce pathological pain by direct actions on the nervous system? Prostaglandins, Leukotrienes and Essential Fatty Acids, v. 68, n.3, p.219-224, 2003.

22 SENANAYAKE, S.P.J.N.; SHAHIDI, F. Structured lipids: acidolysis of gamma-linolenic acid-rich oils with n3 polyunsaturated fatty acids. Journal of Food Lipids, v., n.4, p.309-323, 2002.

23 SOLOMONS, T. W. G.; FRYHLE, C. B. Organic Chemistry. $8^{\text {th }}$ ed. New York: Wiley, 2003. 1344 p.

24 St.ANGELO, A.J. Lipid oxidation in foods. Critical Review in Food Science and Nutrition, v.36, n.3, p.175-224, 1996.

25 TOR, C.C.; YI, H.J. Polyunsaturated fatty acid concentrates from borage and linseed oil fatty acids. Journal of the American Oil Chemists' Society, v.78, n.5, p.485-488, 2001.

26 VANSCHOONBEEK, K.; MAAT, M. P. Fish oil consumption and reduction of arterial disease. Journal of Nutrition, v.133, n.3, p.657-660, 2003.

27 VIEIRA, T.M.F.S.; REGITANO-DÀRCE, M.A.B.; OETTERER, M. Uso do óleo de palma em alimentos. Boletim da Sociedade Brasileira de Ciência e Tecnologia de Alimentos, Campinas, v.31, n.2, p.186191, 1997.

28 WEN, Z. Y.; CHEN, F. Heterotrophic production of eicosapentaenoic acid by microalgae. Biotechnology Advance, v.21, n.4, p.273-294, 2003.

29 WHO. World Health Organization. Prevention of coronary heart disease. Geneva, 1982. 642 p.

30 YU-POTH, S.; ETHERTON,T.D.; REDDY, C.C.; PEARSNO, T.A., REED, R.; ZHAO, G. Lowering dietary saturated fat and total fat reduces the oxidative susceptibility of LDL in healthy men and women. Journal of Nutrition, v. 130, n.9, p.2228-2237, 2000. 
31 ZAMBIAZI, R.Z. Oxidation reactions of vegetable oils and fats. Revista da Sociedade Brasileira de Ciência e Tecnologia de Alimentos, Campinas, v.33, n.1, p.1-7, 1999.

32 ZAMBIAZI, R.Z; ZAMBIAZI, M.W. Vegetable oil oxidation: effect of endogenous components. Revista da Sociedade Brasileira de Ciência e Tecnologia de Alimentos, Campinas, v.34, n.1, p.22-32, 2000. 